\title{
Pengembangan Perangkat Pembelajaran Berbasis Masalah Berorientasi pada Kemampuan Komunikasi dan Prestasi Belajar Matematika Siswa SMP
}

\author{
Fitratul Wulan Fatmasuci \\ SMP IT Bina Umat Moyudan. Desa Sumberarum, Kec. Moyudan, Sleman 55563, Indonesia \\ Email: fitratulwf11@gmail.com
}

Received: 21 October 2016; Revised: 4 May 2017; Accepted: 5 May 2017

\begin{abstract}
Abstrak
Tujuan penelitian ini adalah menghasilkan perangkat pembelajaran matematika berbasis masalah yang berorientasi pada kemampuan komunikasi dan prestasi belajar matematika yang mempunyai kualitas baik yang terdiri atas rencana pelakanaan pembelajaran (RPP), lembar kerja siswa (LKS), tes kemampuan komunikasi, dan tes prestasi belajar. Penelitian ini adalah penelitian dan pengembangan. Prosedur yang diadaptasi tersebut meliputi tiga tahap yaitu studi pendahuluan, desain produk, dan pengembangan produk. Hasil penelitian menunjukkan bahwa perangkat pembelajaran matematika yang dikembangkan masing-masing memenuhi kriteria valid dengan kategori "baik". Perangkat pembelajaran yang dikembangkan praktis dengan hasil penilaian kepraktisan oleh guru pada kategori "baik", kategori "sangat baik" berdasarkan respon siswa dan kategori "sangat baik" berdasarkan hasil observasi keterlaksanaan pembelajaran. Perangkat pembelajaran yang dikembangkan efektif berdasarkan ketuntasan belajar siswa. Persentase siswa yang tuntas pada tes kemampuan komunikasi matematika mencapai $84,38 \%$ dan pada tes prestasi belajar mencapai $81,25 \%$.
\end{abstract}

Kata Kunci: perangkat pembelajaran, pembelajaran berbasis masalah, kemampuan komunikasi matematika, prestasi belajar

\section{Developing a Problem-Based Learning Instructional Kit Oriented to Junior High School of Mathematical Communication Skills and Learning Achievement}

\begin{abstract}
The research aims to produce a good quality problem-based learning mathematics instructional kit oriented to mathematical communication skills and learning achievement consisting of lesson plans, student worksheets, communication skill test, and learning achievement test. This study was a research and development. The procedure of this model consisted of three steps are define, design and develop. The result shows that the mathematics instructional kit is valid with a "good" category. Learning kit that has been developed was practically shown by results of practicality votes by teachers in category "good", "very good" category based on student's responses and "very good" category based on the observation of learning implementation. Learning kit that has been developed was effective based on student's learning mastery. The percentage of students who achieved the mastery level in communication test is $84.38 \%$ and in learning achievement test is $81.25 \%$.
\end{abstract}

Keywords: instructional kits, problem-based learning, mathematical communication skills, learning achievement

How to Cite: Fatmasuci, F. (2017). Pengembangan perangkat pembelajaran berbasis masalah berorientasi pada kemampuan komunikasi dan prestasi belajar matematika siswa SMP. Jurnal Riset Pendidikan Matematika, 4(1), 32-42. doi:http://dx.doi.org/10.21831/jrpm.v4i1.11325

Permalink/DOI: http://dx.doi.org/10.21831/jrpm.v4i1.11325 


\section{Jurnal Riset Pendidikan Matematika, 4 (1), 2017 - 33}

Fitratul Wulan Fatmasuci

\section{PENDAHULUAN}

Matematika merupakan salah satu pelajaran yang sangat penting diajarkan di sekolah mulai sejak sekolah dasar sampai sekolah menengah baik tingkat pertama maupun tingkat atas, bahkan sampai perguruan tinggi. Matematika mempunyai peranan penting dalam kehidupan manusia, seperti pada perkembangan ilmu pengetahuan, perdagangan dan industri. Matematika juga menyediakan suatu alat komunikasi yang singkat serta berfungsi sebagai alat untuk mendeskripsikan suatu permasalahan.

Pembelajaran matematika adalah proses belajar mengajar matematika menggunakan metode dan langkah-langkah yang sistematis untuk mencapai tujuan tertentu. Oleh sebab itu, dalam prosesnya juga dibutuhkan kerja sama yang baik antara guru dan siswa dalam memahami suatu materi pelajaran. Tiga komponen tersebut merupakan komponen integral yang tidak dapat dipisahkan dalam proses pembelajaran.

Guru memiliki peran yang sangat penting dalam menentukan kuantitas dan kualitas pengajaran. Oleh sebab itu, guru perlu memikirkan dan membuat perencanaan yang baik dalam meningkatkan kesempatan belajar bagi siswa dan memperbaiki kualitas mengajarnya (Daryanto \& Rahardjo, 2012, p. 1). Hal ini menuntut perubahan-perubahan dalam pengorganisasian kelas, penggunaan metode mengajar, maupun sikap, dan karakteristik guru dalam mengelola proses belajar mengajar. Guru dituntut agar mempunyai kemampuan dalam berkomunikasi dan berinteraksi dengan siswa. Kemampuan ini sangat penting karena kemampuan berkomunikasi secara efektif dapat memudahkan siswa menangkap pesan sehingga dapat meningkatkan motivasi belajar. Dalam The National Council of Teachers of Mathematics (2000, p. 61) ditegaskan, untuk mendukung terlaksananya pembelajaran yang efektif, guru harus membangun komunikasi matematis di kelas sehingga para siswa merasa bebas mengemukakan ide, gagasan, dan jawabannya. Dengan adanya komunikasi matematis diharapkan tercapainya tujuan pembelajaran matematika.

Komunikasi matematis merupakan salah satu kemampuan yang harus dibekalkan kepada siswa dalam pendidikan di Indonesia seperti disebutkan dalam Peraturan Pemerintah Nomor 19 tahun 2005 tentang Standar Nasional Pendidikan (Presiden Republik Indonesia, 2005a). Komunikasi merupakan bagian penting dari penalaran awal karena kemampuan komunikasi merupakan prasyarat untuk pengembangan matematika. Alisah \& Dharmawan (2007, p. 23) mengatakan bahwa matematika adalah sebuah bahasa, artinya matematika merupakan sebuah cara mengungkapkan atau menerangkan sesuatu hal dengan cara tertentu.

Bahasa matematika yang digunakan adalah melalui simbol-simbol. Melalui pembelajaran matematika, siswa diharapkan dapat mengkomunikasikan gagasan dengan simbol, tabel, diagram, atau media lain untuk memperjelas keadaan atau masalah (Permendiknas Nomor 23 Tahun 2006). Ilmu matematika didasarkan pada komunikasi dari ide-ide. Oleh karena itu, kemampuan komunikasi matematika juga akan membawa pengaruh pada prestasi belajar siswa.

Beberapa penelitian menunjukkan bahwa kemampuan komunikasi matematis siswa Indonesia masih kurang baik. Shadiq (2007) mendapati kenyataan bahwa di beberapa wilayah Indonesia yang berbeda, sebagian besar siswa mengalami kesulitan dalam menerjemahkan soal kehidupan sehari-hari ke dalam model matematika. Ini menunjukkan bahwa kemampuan komunikasi matematika siswa masih kurang baik. Demikian pula Izzati \& Suryadi (2010) mendapatkan gambaran lemahnya kemampuan komunikasi siswa dikarenakan pembelajaran matematika selama ini masih kurang memberi perhatian terhadap pengembangan kemampuan ini.

Tabel 1. Rata-rata Persentase Menjawab Benar

\begin{tabular}{lccc}
\hline Negara & Knowing & Applying & Reasoning \\
\hline Singapura & $82 \%$ & $73 \%$ & $62 \%$ \\
Korea & $80 \%$ & $73 \%$ & $65 \%$ \\
Jepang & $70 \%$ & $64 \%$ & $56 \%$ \\
Malaysia & $44 \%$ & $33 \%$ & $23 \%$ \\
Thailand & $38 \%$ & $30 \%$ & $22 \%$ \\
Indonesia & $37 \%$ & $23 \%$ & $17 \%$ \\
Rata-rata & $49 \%$ & $39 \%$ & $30 \%$ \\
\hline
\end{tabular}

Sumber (Rosnawati, 2013, p. 2)

Selain kemampuan komunikasi, rendahnya prestasi belajar matematika siswa juga menjadi perhatian penting. TIMSS (Trends in International Mathematics and Science Study) adalah studi internasional tentang prestasi matematika dan sains siswa sekolah lanjutan tingkat pertama. Pada tahun 2003 Indonesia berada pada peringkat ke 35 dari 46 negara, dengan skor rata-rata Indonesia untuk matematika adalah 411. Pada tahun 2007 Indonesia berada pada peringkat ke 36 dengan skor rata-rata Indonesia untuk matematika adalah 397, sedangkan skor rata-rata internasional 500. Serta hasil studi 
TIMSS 2011, Indonesia berada diperingkat ke38 dari 42 negara peserta dengan skor rata-rata 386, sedangkan skor rata-rata internasional 500. Untuk lebih jelasnya lihat Tabel 1, yang menyajikan hasil TIMSS 2011 pada aspek kognitif.

Hasil studi tersebut menunjukkan bahwa kemampuan matematika siswa Indonesia lebih rendah dari siswa negara peserta dalam lingkup Asia. Dari Tabel 1 terlihat bahwa siswa di Indonesia masih rendah kemampuan kognitifnya. Padahal kemampuan ini sangat berpengaruh pada prestasi belajar matematika siswa. Prestasi belajar yang baik akan menunjukkan kualitas pembelajaran matematika.

Proses pembelajaran pada satuan pendidikan diselenggarakan secara interaktif, inspiratif, menyenangkan, menantang dan dapat memotivasi siswa untuk berpartisipasi (Presiden Republik Indonesia, 2005b). Untuk menciptakan pembelajaran yang menarik dan meningkatkan kemampuan komunikasi matematika siswa serta prestasi belajar yang maksimal, guru harus memilih metode dan perangkat pembelajaran matematika yang tepat. Dengan perangkat pembelajaran yang tepat, diharapkan dapat meningkatkan aktivitas dan kemampuan komunikasi matematika sehingga prestasi belajar pun dapat ditingkatkan.

Bangun ruang merupakan materi pelajaran matematika yang sudah dikenal siswa sejak sekolah dasar (SD). Namun pemahaman konsep bangun ruang yang dipelajari di SD masih sebatas konsep dasar yang masih dangkal sehingga perlu pemahaman yang mendasar tentang konsep itu untuk memperdalamnya di sekolah menengah. Apabila bekal pemahaman siswa masih rendah maka siswa akan mengalami kesulitan untuk memahami materi bangun ruang di sekolah tingkat berikutnya (Sari, 2016, p. 111). Siswa ternyata masih lemah dalam menyelesaikan soal terkait konten geometri, khususnya dalam pemahaman ruang dan bentuk. Sebagai ilustrasi disajikan soal PISA 2000 sebagai berikut (Wardhani \& Rumiati, 2011, p. 54).

Hasil menunjukkan bahwa siswa-siswi di Indonesia hanya $33,4 \%$ yang menjawab benar dan sisanya 58,79\% menjawab salah. Selain itu, penelitian yang dilakukan oleh (Sulistyani \& Retnawati, 2015, p. 198) mengatakan bahwa pemahaman siswa pada materi bangun ruang masih cenderung lemah. Tentu hal ini harus menjadi perhatian bagi para pendidik maupun peneliti pendidikan bahwa materi geometri khususnya pada bangun ruang sisi datar masih perlu diperdalam dalam pembelajaran di kelas.

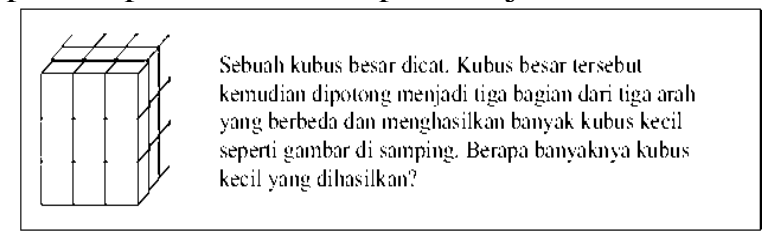

\section{Gambar 1. Soal PISA 2000}

Tabel 2 menyajikan perkembangan penguasaan materi pada pelajaran matematika. Khususnya materi bangun ruang sisi datar pada siswa SMP/MTs lingkup Nasional dan Daerah Istimewa Yogyakarta (DIY).

Berdasarkan Tabel 2, terlihat bahwa beberapa sub materi bangun ruang sisi datar dalam tiga tahun terakhir ini mengalami penurunan rata-rata. Salah satu penyebab penurunan ini adalah kurangnya kemampuan siswa dalam memahami maupun memecahkan masalah matematika khususnya pada materi bangun ruang sisi datar. Kemampuan komunikasi matematika sangat diperlukan dalam mengatasi masalah ini sehingga prestasi siswa pun dapat meningkat.

Melihat kondisi tersebut, perlu adanya inovasi dalam kegiatan pembelajaran di sekolah. Salah satu metode pembelajaran yang dapat meningkatkan aktivitas dan kemampuan komunikasi matematika siswa sehingga belajar akan lebih bermakna adalah metode pembelajaran berbasis masalah (Problem Based Learning). Metode pembelajarannya dimulai dengan pemberian masalah dan biasanya masalah diambil berdasarkan konteks dengan dunia nyata. Siswa secara berkelompok aktif merumuskan masalah, mengidentifikasi pengetahuan mereka, mempelajari dan mencari sendiri materi yang terkait dengan masalah dan melaporkan solusi dari masalah yang diberikan (Amir, 2010, p. 12).

Tabel 2. Perkembangan Penguasaan Materi

\begin{tabular}{lccc}
\hline \multirow{2}{*}{ Materi } & \multicolumn{3}{c}{ Rata-rata } \\
\cline { 2 - 4 } & TA. 2012/2013 & TA. 2013/2014 & TA. 2014/2015 \\
\hline Unsur-unsur pada bangun ruang & 86,42 & 58,81 & 55,87 \\
Jaring-jaring bangun ruang & 55,68 & 85,79 & 54,33 \\
Luas permukaan bangun ruang & 48,37 & 53,53 & 48,16 \\
Volume bangun ruang & 52,66 & 58,76 & 60,92 \\
\hline
\end{tabular}


Metode pembelajaran berbasis masalah mempunyai ciri yaitu pada awal proses belajar mengajar di dalam kelas, siswa terlebih dahulu diberi permasalahan pada kehidupan nyata terkait dengan materi bangun ruang sisi datar. Setelah itu, tugas guru adalah merangsang siswa untuk aktif berpikir dan menuangkan idenya dalam tulisan sehingga hal ini akan merangsang kemampuan komunikasi matematika siswa dalam memecahkan masalah yang ada. Tugas guru adalah mengarahkan siswa untuk bertanya, membuktikan asumsi dan mendengarkan perspektif yang berbeda dengan mereka.

Tan, Chye, \& Teo (2009, p. 9) mengatakan bahwa: The problem-based learning (PBL) process essentially consists of the following stages: (1) meeting the problem; (2) problem analysis and generation of learning issues; (3) discovery and reporting; (4) solution presentation and reflection; and (5) overview, integration and evaluation, with self-directed lerning bridging one stage and the next. Sementara itu, menurut Savery \& Duffy (1995, p. 16), The process of PBL: The students begin the problem. They discuss the problem, generating hypothesis based on whataver experience or knowledge they have, identifying learning issues. A session is not complete until each student has an opportunity to present of problem in front of class and verbally reflect on their current belief is about the diagnosis.

Agar penerapan metode pembelajaran berbasis masalah dapat maksimal digunakan dalam kegiatan pembelajaran, peneliti mencoba memadukan metode belajar tersebut dengan lembar kerja siswa (LKS) yang juga berbasis masalah. Hal ini akan membantu siswa dalam memahami konsep materi dan memacu kemampuan siswa dalam mengomunikasikan gagasan atau ide secara matematis.

Oleh karena itu, penelitian ini bertujuan untuk menghasilkan perangkat pembelajaran matematika berbasis masalah yang berorientasi pada kemampuan komunikasi dan prestasi belajar matematika yang mempunyai kualitas baik yang terdiri atas rencana pelakanaan pembelajaran (RPP), lembar kerja siswa (LKS), tes kemampuan komunikasi, dan tes prestasi belajar.

\section{METODE}

Jenis penelitian ini adalah penelitian dan pengembangan (Research and Development) yaitu penelitian yang berorientasi untuk mengembangkan dan memvalidasi produk yang dikembangkan. Model pengembangan dalam penelitian ini diadaptasi dari model pengembangan Gall, Gall, \& Borg (2007) dan Sukmadinata (2013, p. 184) dengan melakukan modifikasi. Prosedur yang diadaptasi tersebut meliputi tiga tahap yaitu (1) tahap studi pendahuluan, (2) tahap desain produk, dan (3) tahap pengembangan dan evaluasi. Penelitian dilaksanakan di SMP N 1 Moyudan Sleman. Adapun subjek penelitian adalah guru mata pelajaran matematika dan siswa kelas VIII A SMP N 1 Moyudan yang terdiri atas 32 siswa.

Prosedur pengembangan dalam penelitian ini yaitu pertama tahap studi pendahuluan. Tahap ini merupakan tahap pertama atau persiapan untuk pengembangan. Tahap ini terdiri atas studi putsaka dan survei lapangan. Survei lapangan dilakukan dengan tujuan untuk memperoleh data tentang perangkat pembelajaran yang digunakan oleh guru, strategi pembelajaran yang digunakan dan kompetensi matematika yang dimiliki siswa kelas VIII SMP. Survei lapangan ini dilakukan dengan wawancara terhadap guru matematika kelas VIII SMP.

Hasil dari wawancara guru dan beberapa siswa menunjukkan bahwa siswa-siswi SMP mempunyai karakteristik yang berbeda-beda, mulai dari latar belakang sosial maupun kemampuan belajarnya yang meliputi siswa yang mempunyai prestasi tinggi, sedang dan rendah. Metode pembelajaran yang dipakai guru cenderung bervariasi tetapi metode pembelajaran langsung (ceramah) yang sering digunakan dalam proses belajar. Sumber belajar yang digunakan adalah buku paket matematika dan lembar kerja siswa (LKS) yang berisi soal-soal latihan pilihan ganda. Materi pelajaran dalam LKS hanya diuraikan secara singkat dan kurang memfasilitasi siswa dalam mengasah kemampuan komunikasi matematis secara tertulis.

Pada tahap studi pustaka, peneliti melakukan kajian terhadap konsep-konsep atau teoriteori yang berkenaan dengan metode pembelajaran berbasis masalah (Problem Based Learning) dan perangkat pembelajaran yang dikembangkan. Kajian yang dilakukan meliputi kajian terhadap kurikulum tingkat satuan pendidikan (KTSP) tahun 2006 pada mata pelajaran matematika kelas VIII SMP meliputi tujuan pembelajaran matematika, standar kompetensi, kompetensi dasar maupun materi pelajaran. Selanjutnya juga dilakukan kajian terhadap hasil-hasil penelitian yang relevan berkaitan dengan metode pembelajaran berbasis masalah dan kajian pustaka tentang teori pembelajaran matematika. 


\section{Jurnal Riset Pendidikan Matematika, 4 (1), 2017 - 36}

Fitratul Wulan Fatmasuci

Tahap yang kedua yaitu Tahap Desain Produk. Pada tahap ini peneliti mencoba untuk menyusun perangkat pembelajaran matematika berbasis masalah berorientasi pada kemampuan komunikasi dan prestasi belajar matematika siswa. Perangkat yang dikembangkan meliputi Rencana Pelaksanaan Pembelajaran (RPP), Lembar Kerja Siswa (LKS), soal tes kemampuan komunikasi, dan tes prestasi belajar. LKS yang dikembangkan yaitu difokuskan pada materi bangun ruang sisi datar, meliputi kubus, balok, prisma dan limas.

Tahap yang ketiga yaitu tahap Pengembangan dan Evaluasi. Draft produk yang telah dihasilkan kemudian diujicobakan untuk pengembangan lebih lanjut. Uji coba yang dilakukan meliputi tiga tahap yaitu uji ahli dan praktisi, uji coba terbatas, dan uji coba diperluas. Uji ahli dan praktisi dilakukan unuk menguji kevalidan produk berupa perangkat pembelajaran matematika berbasis masalah. Hasil validasi dijadikan dasar untuk mengevaluasi dan merevisi draft awal perangkat sebelum diujicobakan. Pada tahap uji coba terbatas dan uji coba diperluas, dilakukan pembelajaran menggunakan perangkat pembelajaran berbasis masalah yang dikembangkan dan dilakukan pengamatan. Hasil uji coba kemudian dijadikan dasar untuk evaluasi dan perbaikan produk sehingga dihasilkan produk akhir.

Jenis data dalam penelitian ini menggunakan jenis data kuantitatif dan kualitatif. Dalam penelitian ini, instrumen pengumpulan data yang digunakan peneliti untuk mendapatkan data tentang kevalidan, kepraktisan, dan keefektifan. Data kevalidan diperoleh menggunakan lembar validasi yang sumbernya dari ahli yaitu dosen pendidikan matematika. Sementara itu, data kepraktisan diperoleh dari lembar penilaian guru, lembar penilaian siswa, dan lembar observasi keterlaksanaan pembelajaran. Selanjutnya, data keefektifan diperoleh dengan menggunakan tes untuk mengukur prestasi dan tes kemampuan komunikasi matematika siswa.

Analisis data dilakukan untuk mendapatkan produk perangkat pembelajaran dengan metode pembelajaran berbasis masalah (Problem Based Learning) yang berkualitas dan memenuhi aspek kevalidan, kepraktisan, dan keefektifan. Data yang telah terkumpul selanjutnya dianalisis. Pada analisis data kevalidan dan kepraktisan data dianalisis sehingga terkelompok berdasarkan beberapa interval (Widoyoko, 2013, p. 238) yang terpapar pada Tabel 3.
Tabel 3. Konversi Data

\begin{tabular}{cc}
\hline Rentang Skor & Kategori \\
$\bar{x}>M_{i}+1,8 S B_{i}$ & Sangat Baik \\
$M_{i}+0,6 S B_{i}<\bar{x} \leq M_{i}+1,8 S B_{i}$ & Baik \\
$M_{i}-0,6 S B_{i}<\bar{x} \leq M_{i}+0,6 S B_{\bar{i}}$ & Cukup \\
$M_{i}-1,8 S B_{i}<\bar{x} \leq M_{i}-0,6 S B_{i}$ & Kurang \\
$\bar{x} \leq M-1,8 S B_{i}$ & Sangat Kurang
\end{tabular}

Keterangan :

$\bar{x} \quad=$ skor rata-rata

$\mathrm{Mi}=\frac{1}{2}($ skor maks + skor $\min )$

$S b_{i}=\frac{1}{6}$ (skor maks - skor min $)$

Teknik analisis data kevalidan bertujuan untuk mengetahui apakah perangkat pembelajaran yang dibuat telah memenuhi kriteria kevalidan berdasarkan penilaian para ahli atau belum. Proses analisis data kevalidan dilakukan dengan langkah-langkah yaitu: (1) merekap skor penilaian ahli yang diperoleh dalam bentuk skala lima, (2) menghitung total skor yang diberikan oleh setiap validator pada setiap perangkat pembelajaran. (3) menghitung ratarata dari skor yang diperoleh pada poin 2 , dan (4) hasil yang diperoleh pada poin 3 dikonversi menjadi kualitatif sesuai dengan Tabel 3, sehingga diperoleh kategori kevalidan setiap perangkat. Perangkat pembelajaran matematika berbasis masalah dikatakan valid jika rata-rata penilaian ahli minimal dalam kategori "baik" untuk masing-masing perangkat pembelajaran.

Analisis selanjutnya yaitu analisis kepraktisan meliputi analisis data penilaian guru. Kepraktisan perangkat pembelajaran yang dikembangkan salah satunya berdasarkan hasil penilaian guru yang menggunakan perangkat pembelajaran berupa RPP, LKS, tes kemampuan komunikasi dan tes prestasi belajar. Data lembar penilaian guru yang diperoleh kemudian dijumlahkan, lalu dikonversi menjadi data kualitatif skala lima dengan mengacu pada konversi Tabel 3. Perangkat pembelajaran matematika berbasis masalah yang dikembangkan dikatakan praktis jika penilaian guru minimal dalam kategori "baik".

Analisis kepraktisan selanjutnya yaitu analisis data penilaian siswa. Dalam proses analisis data penilaian siswa, dilakukan dengan langkah-langkah yaitu: (a) merekap skor penilaian siswa, (b) menghitung total skor masingmasing siswa, (c) menghitung rata-rata dari skor yang diperoleh pada butir b, sebagai skor aktual (d) Hasil yang diperoleh pada butir c) kemudian 
dikonversi menjadi data kualitatif sesuai dengan Tabel 3, sehingga diperoleh kategori kepraktisan yang ditinjau dari penilaian siswa. Perangkat pembelajaran matematika berbasis masalah yang dikembangkan dikatakan praktis jika penilaian siswa minimal dalam kategori "baik".

Analisis kepraktisan yang terakhir yaitu analisis data lembar observasi keterlaksanaan pembelajaran. Analisis dilakukan dengan menghitung persentase keterlaksanaan kegiatan pembelajaran matematika pada setiap pertemuan kemudian dikonversi menjadi data kualitatif sesuai dengan Tabel 3. Perangkat pembelajaran matematika berbasis masalah yang dikembangkan dikatakan praktis jika persentase keterlaksanaan pembelajaran minimal dalam kategori "baik".

Analisis Keefektifan dalam penelitian ini meliputi analisis tes prestasi belajar dan tes kemampuan komunikasi matematika. Langkahlangkah dalam analisis data tes prestasi belajar matematika yaitu (1) menentukan nilai yang diperoleh masing-masing siswa, (2) menentukan banyaknya siswa yang telah memenuhi Kriteria Ketuntasan Minimal (KKM). Perangkat pembelajaran berbasis masalah yang dikembangkan dikatakan efektif apabila minimal $80 \%$ siswa telah mencapai KKM yang ditetapkan oleh sekolah yaitu 75 .

Selanjutnya, langkah analisis pada tes kemampuan komunikasi matematika yaitu (1) menentukan skor total yang diperoleh masingmasing siswa, (2) menentukan nilai yang diperoleh masing-masing siswa, (3) Menentukan banyaknya siswa yang telah memenuhi Kriteria Ketuntasan Minimal (KKM). Perangkat pembelajaran berbasis masalah yang dikembangkan dikatakan efektif apabila minimal $80 \%$ siswa telah mencapai KKM pada mata pelajaran matematika yang ditetapkan oleh sekolah yaitu 75 .

\section{HASIL DAN PENGEMBANGAN}

\section{Hasil Pengembangan Produk Awal}

Proses pengembangan dimulai dengan membuat draft awal produk. RPP yang disusun untuk draft awal adalah sebanyak delapan RPP untuk delapan kali pertemuan. RPP yang dikembangkan yaitu satu Standar Kompetensi (SK) yang terdiri atas tiga Kompetensi Dasar (KD). Adapun penjabaran SK dan KD terpapar dalam Tabel 4.

Pengembangan produk selanjutnya yaitu LKS. Pada prinsipnya LKS disesuaikan dengan urutan materi bangun ruang sisi datar. LKS yang disusun untuk draft awal adalah sebanyak delapan LKS untuk delapan kali pertemuan. LKS yang dikembangkan untuk satu SK yang terdiri atas tiga KD terkait dengan materi bangun ruang sisi datar. Penjabaran LKS setiap pertemuan disajikan pada Tabel 5 .

Tabel 4. SK dan KD yang dikembangkan

\begin{tabular}{ll}
\hline $\begin{array}{c}\text { Standar Kompetensi } \\
\text { (SK) }\end{array}$ & \multicolumn{2}{l}{ Kompetensi Dasar (KD) } \\
\hline 5. Memahami sifa- & 5.1 Mengidentifikasi sifat- \\
sifat kubus, balok, sifat kubus, balok, prisma \\
prisma, limas dan dan limas serta bagian- \\
bagian-bagiannya & $\begin{array}{l}\text { bagiannya } \\
\text { serta menentukan }\end{array}$ \\
ukurannya. & kubus, balok, prisma dan \\
& limas \\
& 5.3 Menghitung luas permu- \\
& kaan dan volume kubus, \\
& balok, prisma dan limas \\
\hline
\end{tabular}

Tabel 5. Daftar Materi LKS Setiap Pertemuan

\begin{tabular}{cl}
\hline Pert. ke- & \multicolumn{1}{c}{ Daftar LKS } \\
\hline 1 & LKS 1. Sifat-sifat Kubus \& Balok \\
2 & LKS 2. Sifat-sifat Prisma \& Limas \\
3 & LKS 3. Jaring-jaring Kubus \& Balok \\
4 & LKS 4. Jaring-jaring Prisma \& Limas \\
5 & LKS 5. Luas Permukaan Kubus \& Balok \\
6 & LKS 6. Luas Permukaan Prisma \& Limas \\
7 & LKS 7. Volume Kubus \& Balok \\
8 & LKS 8. Volume Prisma \& Limas \\
\hline
\end{tabular}

Tabel 6. Kisi-kisi Tes Kemampuan Komunikasi Matematika

\begin{tabular}{ll}
\hline \multicolumn{1}{c}{ Indikator Kemampuan Komunikasi } & $\begin{array}{c}\text { No. } \\
\text { Soal }\end{array}$ \\
\hline $\begin{array}{l}\text { Menuliskan apa yang diketahui dan apa yang } \\
\text { ditanyakan dengan menggunakan notasi } \\
\text { (simbol), istilah (kosa kata) yang tepat dan }\end{array}$ & $\begin{array}{l}1 \mathrm{a}, \\
\text { lengkap }\end{array}$ \\
$\begin{array}{l}\text { Membuat gambar (model) dengan tepat dan } \\
\text { lengkap }\end{array}$ & $1 \mathrm{~d}$ \\
$\begin{array}{l}\text { Menggunakan persamaan atau rumus } \\
\text { matematika yang tepat }\end{array}$ & $1 \mathrm{~b}$, \\
& $2 \mathrm{~b}$, \\
Menuliskan kesimpulan jawaban dengan & $3 \mathrm{~b}$ \\
tepat. & $1 \mathrm{c}$, \\
& $2 \mathrm{c}$, \\
\hline
\end{tabular}

Penyajian materi dalam LKS mengikuti tahapan metode pembelajaran berbasis masalah yaitu adanya kegiatan mengorientasikan siswa pada masalah sehingga akan mendorong siswa maupun kelompok untuk belajar. Selain itu juga adanya kegiatan menyajikan hasil kerja kelompok dan mengevaluasi proses pemecahan masalah. Pengembangan LKS juga mengacu pada upaya untuk menumbuhkembangkan kemampuan komunikasi matematika siswa. Ahli 
menyarankan bahwa LKS tersebut harus memuat indikator dari kemampuan komunikasi matematis.

Pengembangan selanjutnya yaitu tes kemampuan komunikasi. Tes ini dikembangkan berdasarkan empat aspek perumusan indikator terkait dengan materi bangun ruang sisi datar. Adapun penjabaran kisi-kisi tes kemampuan komunikasi matematis terdapat pada Tabel 6 .

Tes ini terdiri atas tiga buah soal uraian yang bertujuan untuk melihat sejauh mana kemampuan komunikasi matematika siswa khususnya kelas VIIIA SMP N 1 Moyudan dalam menguasai materi bangun ruang sisi datar. Perangkat pembelajaran berbasis masalah yang dikembangkan dikatakan efektif apabila minimal $80 \%$ siswa telah mencapai KKM mata pelajaran matematika yang ditetapkan sekolah yaitu 75 .

Pengembangan yang terakhir yaitu tes hasil belajar. Tes ini dikembangkan berdasarkan perumusan indikator pencapaian hasil belajar. Tes hasil belajar pada draft awal berbentuk soal pilihan ganda yang terdiri atas 30 soal yang disusun berdasarkan SK dan KD pada materi bangun ruang sisi datar. Tes ini akan diberikan kepada siswa setelah pembelajaran menggunakan perangkat pembelajaran berbasis masalah selesai. Tes prestasi sangat penting untuk melihat sejauh mana kemampuan siswa dalam menguasai tujuan suatu pembelajaran khususnya bangun ruang sisi datar. Perangkat pembelajaran berbasis masalah yang dikembangkan dikatakan efektif apabila minimal $80 \%$ siswa telah mencapai KKM yang ditetapkan sekolah yaitu 75.

\section{Hasil Uji Coba Produk}

Tabel 7. Analisis Validasi RPP

\begin{tabular}{lc}
\hline \multicolumn{1}{c}{ Aspek penilaian RPP } & $\begin{array}{c}\text { Skor rata- } \\
\text { rata }\end{array}$ \\
\hline Identitas mata pelajaran & 4,55 \\
Rumusan tujuan & 4,55 \\
Pemilihan materi & 3,88 \\
Metode pembelajaran & 4,00 \\
Kegiatan pembelajaran & 3,90 \\
Penutup & 4,50 \\
Pemilihan sumber belajar & 4,00 \\
Penilaian hasil belajar & 3,90 \\
Penerapan pembelajaran berbasis & 3,90 \\
masalah $\quad$ Rata-rata skor & $\mathbf{4 , 0 5}$ \\
\multicolumn{1}{c}{ Jumlah skor rata-rata } & $\mathbf{1 3 4}$ \\
\hline
\end{tabular}

Data hasil uji coba perangkat pembelajaran terdiri atas: (1) Hasil dari validasi para ahli, (2) hasil uji coba terbatas, dan (3) hasil uji coba diperluas. Berikut disajikan tabel analisis validasi RPP, LKS, tes kemampuan komunikasi dan tes prestasi belajar.

Berdasarkan Tabel 7, diperoleh hasil validasi ahli pada RPP dengan rata-rata skor adalah 4,05 dan jumlah skor rata-rata 134. Sehingga bisa dikatakan bahwa perangkat pembelajaran matematika berupa RPP berbasis masalah tersebut valid pada kategori baik. Sedangkan untuk hasil validasi LKS dapat dilihat pada Tabel 8 .

Tabel 8. Analisis Validasi LKS

\begin{tabular}{|c|c|}
\hline Aspek Penilaian LKS & $\begin{array}{c}\text { Skor Rata- } \\
\text { Rata Ahli }\end{array}$ \\
\hline Identitas dan petunjuk & 4,25 \\
\hline Alokasi waktu & 4,00 \\
\hline Tujuan pembelajaran & 4,50 \\
\hline Prosedur kegiatan & 4,33 \\
\hline Tampilan & 4,50 \\
\hline Bahasa & 3,88 \\
\hline Isi & 4,00 \\
\hline Pertanyaan & 3,83 \\
\hline $\begin{array}{l}\text { Kesesuaian dengan pembelajaran } \\
\text { berbasis masalah }\end{array}$ & 3,90 \\
\hline Rata-rata skor & 4,1 \\
\hline Jumlah skor rata-rata & 119 \\
\hline Kategori & Baik \\
\hline
\end{tabular}

Berdasarkan Tabel 8, diperoleh hasil validasi ahli pada LKS dengan rata-rata skor adalah 4,1 dan jumlah skor rata-rata 119 yaitu pada kategori baik. Sehingga bisa dikatakan bahwa perangkat pembelajaran matematika berupa LKS berbasis masalah tersebut valid pada kategori baik. Tabel 9 menyajikan hasil validasi tes kemampuan komunikasi.

Tabel 9. Analisis Validasi Tes Kemampuan Komunikasi Matematika

\begin{tabular}{lc}
\hline \multicolumn{1}{c}{ Aspek Penilaian } & Skor rata-rata ahli \\
\hline Materi & 0,72 \\
Konstruksi & 0,89 \\
Bahasa & 0,78 \\
$\quad$ Rata-rata skor & $\mathbf{0 , 8 0}$ \\
Jumlah skor rata-rata & $\mathbf{2 1 , 5}$ \\
$\quad$ Kategori & Baik \\
\hline
\end{tabular}

Berdasarkan Tabel 9, diperoleh skor ratarata keseluruhan aspek tes kemampuan komunikasi yaitu 0,80 dari skor maksimal 1 dan ratarata jumlah skor penilaian ahli yaitu 21,5. Sehingga bisa dikatakan bahwa tes kemampuan komunikasi matematika tersebut valid dengan kategori Baik. Berikut juga disajikan hasil validasi tes prestasi belajar matematika pada Tabel 10. 
Tabel 10. Validasi Tes Prestasi Belajar

\begin{tabular}{lc}
\hline \multicolumn{1}{c}{ Aspek Penilaian } & Skor rata-rata ahli \\
\hline Materi/ Isi & 4,00 \\
Kesesuaian Penyajian & 4,00 \\
Kesesuaian Bahasa & 3,83 \\
Rata-rata skor & $\mathbf{3 , 9 4}$ \\
Jumlah skor rata-rata & $\mathbf{7 9 , 5}$ \\
$\quad$ Kategori & Baik \\
\hline
\end{tabular}

Berdasarkan Tabel 10, diperoleh hasil validasi ahli pada tes prestasi belajar dengan rata-rata skor keseluruhan aspek adalah 3,94 dan jumlah skor rata-rata 119 . Sehingga dapat dikatakan bahwa perangkat pembelajaran matematika berupa tes prestasi belajar tersebut valid pada kategori baik. Selanjutnya, akan dipaparkan tentang hasil analisis kepraktisan meliputi penilaian guru, respon siswa dan hasil lembar observasi keterlaksanaan pembelajaran matematika.

Tabel 11. Analisis Kepraktisan Guru

\begin{tabular}{cc}
\hline Indikator Penilaian & Skor rata-rata guru \\
\hline RPP & 4,00 \\
LKS & 4,00 \\
Rata-rata skor & $\mathbf{4 , 0 0}$ \\
Jumlah skor rata-rata & $\mathbf{4 4}$ \\
Kategori & Baik \\
\hline
\end{tabular}

Berdasarkan tabel 11, diperoleh skor ratarata keseluruhan indikator penilaian guru yaitu 4,00 dengan jumlah skor rata-rata 44. Oleh karena itu, bisa dikatakan bahwa perangkat pembelajaran yang dikembangkan tersebut praktis dengan kategori baik. Berikut juga disajikan hasil analisis kepraktisan siswa uji coba terbatas dan uji coba luas.

Tabel 12. Kepraktisan Siswa Uji coba Terbatas

\begin{tabular}{cccc}
\hline $\begin{array}{c}\text { Banyak } \\
\text { Siswa }\end{array}$ & $\begin{array}{c}\text { Rata- } \\
\text { rata Skor }\end{array}$ & $\begin{array}{c}\text { Jumlah skor } \\
\text { rata-rata }\end{array}$ & Kategori \\
\hline 10 & 4,00 & 28 & Baik \\
\hline \multicolumn{3}{c}{ Tabel } & 13. Kepraktisan Siswa Uji coba Luas \\
\hline $\begin{array}{c}\text { Banyak } \\
\text { Siswa }\end{array}$ & $\begin{array}{c}\text { Rata- } \\
\text { rata } \\
\text { Skor }\end{array}$ & $\begin{array}{c}\text { Jumlah Skor } \\
\text { rata-rata }\end{array}$ & Kategori \\
\hline 32 & 4,29 & 30 & $\begin{array}{c}\text { Sangat } \\
\text { Baik }\end{array}$ \\
\hline \multicolumn{5}{c}{ Berdasarkan Tabel 12 dan Tabel 13, pada }
\end{tabular}

uji coba terbatas sebanyak 10 siswa memperoleh rata-rata respon terhadap pengembangan perangkat pembelajaran yaitu 4,00 dengan kategori baik. Sedangkan pada uji coba luas, sebanyak 32 siswa memperoleh rata-rata respon terhadap pengembangan perangkat pembelajaran yaitu 4,29 pada kategori sangat baik. Berikut juga disajikan analisis hasil observasi keterlaksanaan pembelajaran.

Tabel 14. Analisis Lembar Observasi Keterlaksanaan Pembelajaran

\begin{tabular}{cccc}
\hline Pert. & $\begin{array}{c}\text { Persentase } \\
\text { Keterlaksanaan }\end{array}$ & $\begin{array}{c}\text { Rata- } \\
\text { rata }\end{array}$ & Kategori \\
\hline 1 & $75 \%$ & & \\
2 & $83 \%$ & & \\
3 & $90 \%$ & & \\
4 & $95 \%$ & $90,63 \%$ & Sangat \\
5 & $92 \%$ & & Baik \\
6 & $95 \%$ & & \\
7 & $95 \%$ & & \\
8 & $100 \%$ & & \\
\hline
\end{tabular}

Berdasarkan Tabel 14, diperoleh rata-rata jumlah skor 21,4 dengan rata-rata persentase keterlaksanaan pembelajaran matematika yaitu $90,63 \%$, artinya persentase pembelajarannya telah melebihi kriteria minimal yaitu $80 \%$. Oleh karena itu, perangkat pembelajaran matematika berbasis masalah dapat dikatakan praktis dengan kategori sangat baik. Selanjutnya, akan disajikan hasil analisis keefektifan perangkat pembelajaran yang terdiri atas tes kemampuan komunikasi dan tes prestasi belajar matematika.

Tabel 15. Analisis Keefekifan Tes Kemampuan Komunikasi Matematika

\begin{tabular}{cccc}
\hline $\begin{array}{c}\text { Banyak } \\
\text { Siswa }\end{array}$ & $\begin{array}{c}\text { Banyak } \\
\text { siswa yang } \\
\text { tuntas }\end{array}$ & $\begin{array}{c}\text { Rata- } \\
\text { rata } \\
\text { nilai }\end{array}$ & $\begin{array}{c}\text { Persentase } \\
\text { Kelulusan }\end{array}$ \\
\hline 32 & 27 & 81,88 & $84,38 \%$ \\
\hline \multicolumn{3}{c}{ Berdasarkan Tabel } & 15 , diperoleh rata-rata
\end{tabular}
nilai kemampuan komunikasi matematis siswa kelas VIII A SMP N 1 Moyudan yaitu sebesar 81,88. Kriteria Ketuntasan Minimal (KKM) untuk mata pelajaran matematika yang ditetapkan yaitu 75 . Terdapat 27 dari 32 siswa yang dinyatakan tuntas. Selain itu, persentase ketuntasan secara klasikal yang dicapai sebesar $84,38 \%$. Oleh karena itu, bisa dikatakan bahwa tes kemampuan komunikasi tersebut efektif.

Tabel 16. Analisis Keefektifan Tes Prestasi Belajar Matematika

\begin{tabular}{cccc}
\hline $\begin{array}{c}\text { Banyak } \\
\text { Siswa }\end{array}$ & $\begin{array}{c}\text { Banyak } \\
\text { siswa yang } \\
\text { tuntas }\end{array}$ & $\begin{array}{c}\text { Rata- } \\
\text { rata } \\
\text { nilai }\end{array}$ & $\begin{array}{c}\text { Persentase } \\
\text { Kelulusan }\end{array}$ \\
\hline 32 & 26 & 83,85 & $81,25 \%$ \\
\hline
\end{tabular}

Berdasarkan Tabel 16, diperoleh rata-rata nilai tes prestasi belajar matematika siswa yaitu 83,85 dengan persentase kelulusan $81,25 \%$. KKM untuk mata pelajaran matematika yang ditetapkan di SMP N 1 Moyudan yaitu 75. Hal tersebut berarti bahwa rata-rata nilai tes prestasi 
matematika untuk kelas VIII A SMP N 1 Moyudan berada di atas KKM yang ditetapkan. Terdapat 26 dari 32 siswa yang tuntas. Oleh karena itu, bisa dikatakan bahwa perangkat pembelajaran matematika berupa tes prestasi belajar matematika efektif.

\section{Kajian Produk Akhir}

Prodak pengembangan pada akhirnya haruslah memiliki kualitas yang baik sehingga dapat dimanfaatkan oleh pihak terkait. Menurut Nieveen (1999, p. 126), produk pengembangan yang berkualitas harus memenuhi kriteria kevalidan, kepraktisan dan keefektifan. Oleh karena itu, berdasarkan hasil validasi ahli dan uji coba diperluas diketahui bahwa perangkat pembelajaran yang dikembangkan telah memenuhi kriteria valid, praktis dan efektif ditinjau dari kemampuan komunikasi dan prestasi belajar matematika.

Kevalidan perangkat pembelajaran matematika diperoleh dari penilaian ahli. Berdasarkan penilaian para ahli, produk akhir perangkat pembelajaran bangun ruang sisi datar dengan metode berbasis masalah yang terdiri atas Rencana Pelaksanaan Pembelajaran (RPP), Lembar Kerja Siswa (LKS), tes kemampuan komunikasi dan tes prestasi belajar matematika masingmasing telah memenuhi kriteria valid dengan kategori baik. Perangkat pembelajaran bangun ruang sisi datar juga telah direvisi berdasarkan masukan atau saran dari ahli sehingga layak untuk digunakan.

Pada penelitian ini, kepraktisan perangkat pembelajaran didasarkan pada penilaian guru yang menggunakan perangkat pembelajaran yang dikembangkan, respon siswa setelah melaksanakan pembelajaran menggunakan perangkat pembelajaran yang dikembangkan dan hasil observasi keterlaksanaan pembelajaran. Berdasarkan uji coba diperluas, diperoleh hasil penilaian guru bahwa perangkat pembelajaran termasuk pada kategori baik. Adapun masukan dari guru adalah RPP perlu ditambahkan tugas pekerjaan rumah secara berkelompok yaitu membuat alat peraga bangun ruang sisi datar untuk memperkuat pengetahuan siswa. Sedangkan untuk LKS, guru mengatakan bahwa LKS matematika berbasis masalah yang digunakan sudah baik sehingga tidak perlu ada masukan atau revisi.

Berdasarkan pengalaman ketika uji coba diperluas, LKS matematika berbasis masalah langsung diberikan kepada siswa saat pembelajaran dan ternyata siswa dapat mengikuti pembelajaran dengan baik. Pada diskusi kelompok secara heterogen, setiap siswa saling bertukar ide dan pendapat dalam menyelesaikan permasalahan yang terdapat dalam LKS.

Selanjutnya, hasil respon siswa setelah mengikuti pembelajaran dengan menggunakan perangkat pembelajaran yang dikembangkan termasuk pada kategori sangat baik. Hal ini karena tampilan LKS dibuat menarik yaitu disertai gambar-gambar dan masalah-masalah kontekstual agar siswa termotivasi untuk mengetahui lebih lanjut terhadap materi yang disajikan dalam LKS.

Hasil observasi juga menunjukkan bahwa rata-rata persentase keterlaksanaan pembelajaran matematika yaitu sebesar 90,63\% dengan kategori sangat baik. Oleh karena itu, berdasarkan hasil penilaian guru, respon siswa dan hasil observasi keterlaksanaan pembelajaran matematika, maka dapat dikatakan bahwa perangkat pembelajaran yang dihasilkan telah memenuhi kriteria praktis.

Keefektifan perangkat pembelajaran diperoleh dari hasil tes kemampuan komunikasi dan tes prestasi belajar matematika. Berdasarkan uji diperluas yang telah dilaksanakan menunjukkan bahwa perangkat pembelajaran bangun ruang sisi datar dengan metode berbasis masalah yang dihasilkan telah memenuhi kriteria efektif. Hal ini dapat dilihat dari tes kemampuan komunikasi dan tes prestasi belajar matematika yang hasilnya menunjukkan bahwa lebih dari 80\% siswa telah mencapai Kriteria Ketuntasan Minimal (KKM). Dengan persentase ketuntasan yang lebih dari $80 \%$, berarti tujuan pembelajaran telah tercapai dan produk yang dikembangkan secara umum dinilai efektif sehingga layak untuk digunakan.

Efektifnya perangkat pembelajaran matematika ini karena dalam PBL (Problem Based Learning) siswa dihadapkan pada masalahmasalah dunia nyata sehingga mendorong siswa untuk berpikir logis dan mencari solusi dengan mengaitkan permasalahan tersebut dengan rumus matematika. Dalam pembelajaran berbasis masalah terdapat tahap dimana siswa diminta untuk melakukan penyelidikan melalui diskusi kelompok. Setiap anggota kelompok dapat saling bertanya, menjawab, mengkritisi dan mengklarifikasi setiap konsep matematis yang muncul pada permasalahan yang diberikan. Kegiatan ini juga memungkinkan siswa untuk mengumpulkan dan menganalisis informasi, melakukan penyeledikan dan membuat kesimpulan. Dengan demikian, suasana kerja 


\section{Jurnal Riset Pendidikan Matematika, 4 (1), 2017 - 41}

Fitratul Wulan Fatmasuci

kelompok seperti ini dapat meningkatkan kemampuan komunikasi matematika.

Pada tahap penyajian hasil karya, siswa mengomunikasikan hasil diskusi kelompoknya baik secara lisan maupun tertulis kepada guru dan teman-teman sekelas. Pada tahap ini, siswa banyak berlatih tentang bagaimana cara menyampaikan hasil diskusi kelompok yang baik sehingga dapat dipahami kelompok lainnya. Dengan demikian, pembelajaran dengan metode berbasis masalah dapat meningkatkan kemampuan komunikasi matematika siswa.

\section{SIMPULAN}

Berdasarkan hasil penelitian dan pembahasan, diperoleh kesimpulan yaitu perangkat pembelajaran bangun ruang sisi datar dengan metode pembelajaran berbasis masalah (Problem Based Learning) berorientasi pada kemampuan komunikasi dan prestasi belajar matematika untuk siswa kelas VIII SMP yang terdiri atas RPP, LKS, tes kemampuan komunikasi dan tes prestasi belajar matematika masingmasing memenuhi kriteria valid dengan kategori baik.

Perangkat pembelajaran bangun ruang sisi datar dengan metode pembelajaran berbasis masalah yang berorientasi pada kemampuan komunikasi dan prestasi belajar matematika untuk siswa kelas VIII SMP yang terdiri atas RPP dan LKS memenuhi kriteria praktis, dengan kategori kategori sangat baik berdasarkan respon siswa dan kategori baik berdasarkan penilaian guru. Sedangkan berdasarkan hasil observasi, rata-rata keterlaksanaan pembelajaran masuk dalam kategori sangat baik.

Perangkat pembelajaran bangun ruang sisi datar dengan metode pembelajaran berbasis masalah yang berorientasi pada kemampuan komunikasi dan prestasi belajar matematika untuk siswa kelas VIII SMP yang terdidi dari RPP, LKS, tes kemampuan komunikasi dan tes prestasi belajar matematika memenuhi kriteria efektif. Persentase banyaknya siswa yang tuntas pada tes kemampuan komunikasi mencapai $84,38 \%$ dengan rata-rata nilai 81,88 dan tes prestasi belajar mencapai $81,25 \%$ dengan ratarata nilai 83,85 .

\section{DAFTAR PUSTAKA}

Alisah, E., \& Dharmawan, E. P. (2007). Filsafat dunia matematika: Pengantar untuk memahami konsep-konsep matematika. Jakarta: Prestasi Pustaka.

Amir, M. T. (2010). Inovasi pendidikan melalui problem based learning: Bagaimana pendidik memberdayakan pemelajar di era pengetahuan. Jakarta: Prenada Media Group.

Daryanto, \& Rahardjo, M. (2012). Model pembelajaran inovatif. Yogyakarta: Gava Media.

Gall, M. D., Gall, J. P., \& Borg, W. R. (2007). Educational research: An introduction. Pearson/Allyn \& Bacon.

Izzati, N., \& Suryadi, D. (2010). Komunikasi matematik dan pendidikan matematika realistik. In Prosiding Seminar Nasional Matematika dan Pendidikan Matematika (pp. 978-979). Yogyakarta: Universitas Negeri Yogyakarta. Retrieved from https://bundaiza.files.wordpress.com/2012/ 12/komunikasi_matematik_dan_pmrprosiding.pdf

Nieveen, N. (1999). Prototyping to reach product quality. In Design Approaches and Tools in Education and Training (pp. 125135). Dordrecht: Springer Netherlands. http://doi.org/10.1007/978-94-011-42557_10

Presiden Republik Indonesia. Peraturan pemerintah Republik Indonesia no 19 th 2005 tentang standar nasional pendidikan, Peraturan pemerintah Republik Indonesia (2005).

Presiden Republik Indonesia. Peraturan Pemerintah Republik Indonesia nomor 19 tahun 2005 tentang standar nasional pendidikan, Peraturan Pemerintah Republik Indonesia 1-71 (2005).

Rosnawati, R. (2013). Kemampuan penalaran matematika siswa SMP Indonesia pada TIMSS 2011. In Prosiding Seminar Nasional Penelitian, Pendidikan dan Penerapan MIPA (p. M-6). Yogyakarta: Fakultas MIPA, Universitas Negeri Yogyakarta. Retrieved from http://staffnew.uny.ac.id/upload/13200180 8/penelitian/Makalah+Semnas+2013+an+ R+Rosnawati+FMIPA+UNY.pdf

Sari, W. R. (2016). Pengembangan perangkat pembelajaran bangun ruang di SMP dengan pendekatan pendidikan matematika realistik. Jurnal Riset Pendidikan Matematika, $3(1), \quad 109$. http://doi.org/10.21831/jrpm.v3i1.10407

Savery, J. R., \& Duffy, T. M. (1995). Problem based learning: An instructional model and 
its constructivist framework. Educational Technology, 35(5), 31-38.

Shadiq, F. (2007). Laporan hasil seminar dan lokakarya pembelajaran matematika 15 16 Maret 2007 di P4TK (PPPG) matematika. Yogyakarta. Retrieved from https://id.scribd.com/doc/78216950/LAPO RAN-HASIL-SEMINAR-DAN-

LOKAKARYA-PEMBELAJARAN-

MATEMATIKA-15-16-Maret-2007-DIP4TK-PPPG-MATEMATIKA

Sukmadinata, N. S. (2013). Metode penelitian pendidikan. Bandung: PT Remaja Rosdakarya.

Sulistyani, N., \& Retnawati, H. (2015). Pengembangan perangkat pembelajaran bangun ruang di SMP dengan pendekatan problem-based learning. Jurnal Riset Pendidikan Matematika, 2(2), 197-210. http://doi.org/10.21831/JRPM.V2I2.7334

Tan, O.-S., Chye, S., \& Teo, C.-T. (2009). Problem-based learning and creativity: A review of the literature. Singapore: Cengage Learning Asia Pte Ltd. Retrieved from http://www.encyclopedia.com/education/a pplied-and-social-sciencesmagazines/problem-based-learning-andcreativity-review-literature

The National Council of Teachers of Mathematics. (2000). NCTM principles and standards for school mathematics,. Association Drive, Reston, VA: Library of Congres Cataloguing-in-Publication Data. Retrieved from https://www.nctm.org/store/Products/NCT M-Principles-and-Standards-for-SchoolMathematics,-Full-Edition-(PDF)/

Wardhani, S., \& Rumiati. (2011). Instrumen penilaian hasil belajar matematika SMP: Belajar dari PISA dan TIMSS. Yogyakarta. Retrieved from http://p4tkmatematika.org/file/Bermutu 2011/SMP/4.INSTRUMEN PENILAIAN HASIL BELAJAR MATEMATIKA ......pdf

Widoyoko, S. E. P. (2013). Evaluasi program pembelajaran: panduan praktis bagi pendidik dan calon pendidik. Yogyakarta: Pustaka Pelajar. http://doi.org/2013 